\author{
ПЕРСПЕКТИВНІ НАПРЯМИ РОЗВИТКУ \\ ПЕРЕРОБНИХ ПІДПРИЕМСТВ АПК В \\ УМОВАХ ІНТЕГРАЦІЇ У СВІТОВИЙ \\ ЕКОНОМІЧНИЙ ПРОСТІР $\odot$
}

\author{
ГОНТАРУК Я.В., \\ асистент кафедри аграрного \\ менеджменту \\ Вінницький національний \\ аграрний університет \\ (Вінниця)
}

У статті розглянуто сучасний стан розвитку переробної промисловості АПК в умовах інтеграиії у світовий економічний простір. Проаналізовано економічні показники розвитку переробних підприсмств аграрної сфери. Досліджено основні проблеми розвитку підприємств переробних галузей агропромислового комплексу. Досліджено проєкт розпорядження Кабінету Міністрів України «Про схвалення Стратегії розвитку експорту продукції сільського господарства, харчової та переробної промисловості України до 2026 року». Визначено стратегічні напрямки розвитку експорту продукиії харчової промисловості на перспективу. Досліджено практику створення дочірніх підприємств молокозаводами для забезпечення власною молочною сировиною високої якості. Запропоновано заходи з адаптації підприємств переробних в умовах інтеграиії в світовий глобалізований простір. Розроблені пропозиції стосовно виробничої реструктуризаиії спиртових заводів з їхньою переорієнтацією на виробництво біоетанолу. Визначено механізми комплексної реструктуризаиї̈ підприємств окремих переробних галузей АПК. Визначено перспективні напрямки розвитку переробних підприємств аграрної сфери.

Ключові слова: інтеграція, реструктуризація, перспективи, рентабельність, оновлення, стратегія, ефективність.

Табл.: 4. Рис.: 1. Літ.: 11.

\title{
PERSPECTIVE DIRECTIONS OF DEVELOPMENT OF PROCESSING ENTERPRISES OF AGROINDUSTRIAL COMPLEX IN CONDITIONS OF INTEGRATION INTO THE WORLD ECONOMIC SPACE
}

\author{
GONTARUK Yaroslav, \\ assistant of the department \\ of agrarian management \\ Vinnytsia National Agrarian University
}

(Vinnytsya)

The article deals with the current state of development of processing industry of agroindustrial complex in conditions of integration into the world economic space. The economic indicators of the development of processing enterprises of agrarian sphere are analyzed. The main problems of development of enterprises of processing industries of the agroindustrial complex are investigated. The draft order of the Cabinet of Ministers of Ukraine "On Approving the Strategy for Exporting Agricultural Products, Food and Processing Industry of Ukraine to 2026" was explored. The strategic directions of development of export of food products for the future are determined. The practice of setting up subsidiaries for dairy factories to provide their own high quality dairy raw materials is investigated. The measures for the adaptation of the enterprises of the processing industry in the conditions of integration into the globalized globalized space are proposed. Developed proposals for the industrial restructuring of distilleries with their reorientation to bioethanol production. The mechanisms of complex restructuring of enterprises of certain processing industries of agroindustrial complex are determined. The perspective directions of development of processing enterprises of agrarian sphere are determined.

Key words: integration, restructuring, prospects, profitability, updating, strategy, efficiency.

Tabl.: 4. Fig.: 1. Lit.: 11 


\title{
ПЕРСПЕКТИВНЫЕ НАПРАВЛЕНИЯ РАЗВИТИЯ ПЕРЕРАБАТЫВАЮЩИХ ПРЕДПРИЯТИЙ АПК В УСЛОВИЯХ ИНТЕГРАЦИИ В МИРОВОЕ ЭКОНОМИЧЕСКОЕ ПРОСТРАНСТВО
}

\author{
ГОНТАРУК Я.В., \\ ассистент кафедры аграрного менеджмента \\ Винницкий национальный аграрный университет
} (2. Винница)

В статье рассмотрено современное состояние развития перерабатьвающей промышиленности АПК в условиях интеграџии в мировое экономическое пространство. Проанализированы экономические показатели развития перерабатываютих предприятий аграрной сферы. Исследованы основные проблемы развития предприятий перерабатываюших отраслей агропромышленного комплекса. Исследована проект распоряжения Кабинета Министров Украинь «Об одобрении Стратегии развития экспорта продукции сельского хозяйства, пищевой и перерабатывающей промышленности Украины до 2026 года». Определень стратегические направления развития экспорта продукции пищевой промышленности на перспективу. Исследовано практику создания дочерних предприятий молокозаводами для обеспечения собственной молочным сырьем высокого качества. Предложены меры по адаптации предприятий перерабатывающих в условиях интеграчии в мировое глобализированный пространство. Разработанные предложения по производственной реструктуризации спиртовых заводов с их переориентацией на производство биоэтанола. Определены механизмы комплексной реструктуризации предприятий отдельных перерабатывающих отраслей АПК. Определены перспективные направления развития перерабатывающих предприятий аграрной сферы.

Ключевые слова: интеграция, реструктуризация, перспективы, рентабельность, обновления, стратегия, эффективность.

Табл.: 4. Рис.: 1. Лит.: 11.

Постановка проблеми. У сучасних умовах господарювання розвиток переробних підприємств АПК є одним 3 пріоритетних для економіки. За умов світового зростання цін на продовольство, швидких процесів інтеграції та глобалізації визначення перспектив розвитку переробної галузі є однією з головних проблем розробки довгострокової стратегії розвитку економіки України. Значний вплив на діяльність суб'єктів господарювання здійснюють такі чинники зовнішнього середовища як чинна нормативно-правова база, податкова і кредитна політика держави, які, внаслідок своєї недосконалості, ускладнюють проведення процедур з реструктуризації підприємств та їхньої інтеграції у світовий економічний простір. Питання виробничої реструктуризації та диверсифікації виробництва в харчовій промисловості в умовах енергетичної залежності держави є одним 3 ключових при формуванні напрямків економічної інтеграції.

Одним із основних завдань у виборі стратегії розвитку переробних підприємств має стати низка стратегічних заходів, комплексна реалізація яких повною мірою дозволить створити сприятливі умови для підвищення конкурентоспроможності підприємств.

При виборі стратегії розвитку підприємств переробної промисловості вирішальну роль відіграють стан галузі та місце в ній певного підприємства. Підприємства-лідери в сучасних ринкових умовах змушені максимально використовувати свої можливості для зміцнення позиції в галузі. Слабкі підприємства мають обирати стратегії, які допоможуть їм закріпити власні позиції на ринку.

Аналіз останніх досліджень і публікацій. Дослідження проблематики розвитку переробних підприємств АПК проводилося у працях вітчизняних та зарубіжних вчених: Калетніка Г.М. [2], Швеця Ю.О. [3], Конишева В.А. [8], Саєнко Я.А. [9], Підвальної О.Г. [11] та ін. Значний вклад у формування теоретичних засад проведення реструктуризації підприємств цієї галузі здійснили дослідники: А.Г. Мазур [5], Меліх Т.Г. [10] та інші.

У той же час потребують більш грунтовних досліджень напрямки подальшого розвитку підприємств переробних галузей АПК в умовах інтеграції у світовий економічний простір, що й зумовлює актуальність дослідження.

Формулювання цілей статті. Метою дослідження $є$ аналіз розвитку підприємств переробної промисловості в умовах глобалізації соціально-економічних процесів.

Виклад основного матеріалу. У теперішній час аграрна галузь перебуває в стані глибоких трансформаційних змін зумовлених інтеграційними процесами економіки держави в світовий економічний. 
http://efm.vsau.org/

Протягом 2013-2018 років виробництво продукції переробних підприємств АПК мало циклічний характер, на який переважно впливали соціально-економічні чинники, особливо в період 2014-2016 років. У 2018 році спостерігається стагнація у переробній промисловості АПК, спричинена як соціально-політичними процесами, так і відсутністю інструментів щодо адаптації цієї галузі у світовому економічному просторі (табл. 1).

Табличя 1

Індекси промислової продукції за видами діяльності за 2013-2018 роки, (відсотків до попереднього року)

\begin{tabular}{|l|c|c|c|c|c|c|c|}
\hline & 2013p. & 2014p. & 2015p. & 2016p. & 2017p. & 2018p. & $\begin{array}{c}\text { Відхилення, } \\
\text { +,- }\end{array}$ \\
\hline Промисловість & 95,7 & 89,9 & 87,0 & 102,8 & 100,4 & 101,6 & 5,9 \\
\hline Переробна промисловість & 92,7 & 90,7 & 87,4 & 104,3 & 104,8 & 101,1 & 8,4 \\
\hline $\begin{array}{l}\text { Виробництво харчових продуктів, } \\
\text { напої та тютюнових виробів }\end{array}$ & 95,0 & 102,5 & 89,3 & 104,4 & 102,9 & 98,5 & 3,5 \\
\hline Виробництво харчових продуктів & 96,4 & 104,6 & 87,2 & 106,0 & 104,2 & 98,5 & 2,1 \\
\hline $\begin{array}{l}\text { Виробництво м’яса та м'ясних } \\
\text { продуктів }\end{array}$ & 110,5 & 100,5 & 99,8 & 104,5 & 101,3 & 99,1 & $-11,4$ \\
\hline $\begin{array}{l}\text { Перероблення та консервування } \\
\text { риби, ракоподібних і молюсків }\end{array}$ & 105,1 & 98,7 & 71,4 & 115,6 & 106,8 & 112,4 & 7,3 \\
\hline $\begin{array}{l}\text { Перероблення та консервування } \\
\text { фруктів і овочів }\end{array}$ & 99,8 & 102,9 & 74,6 & 100,2 & 105,1 & 110,4 & 10,6 \\
\hline $\begin{array}{l}\text { Виробництво олії та тваринних } \\
\text { жирів }\end{array}$ & 92,6 & 121,5 & 85,8 & 116,5 & 118,7 & 94,5 & 1,9 \\
\hline Виробництво молочних продуктів & 100,5 & 100,1 & 91,2 & 98,6 & 102,1 & 100,4 & $-0,1$ \\
\hline Виробництво цукру & 58,9 & 166,8 & 69,5 & 136,2 & 99,2 & 89,4 & 30,5 \\
\hline
\end{tabular}

Джерело: сформовано на основі [1]

Спад виробництва відбувався і в обсягах виробництва. Найбільший спад відбувався у виробництві курятини, яловичини та свинини. Збільшення обсягів виробництва олії $є$ також досить незначним. Виробництво цукру у 2018 році зменшилося порівняно 2014 роком майже у 2 рази (табл. 2).

Виробництво окремих видів промислової продукції за 2011-2017 роки

Таблиия 2

\begin{tabular}{|c|c|c|c|c|c|c|c|c|}
\hline \multirow{2}{*}{$\begin{array}{c}\text { Найменування продукції } \\
\text { за Номенклатурою } \\
\text { продукції промисловості } \\
\text { (НПП), одиниця } \\
\text { вимірювання }\end{array}$} & \multicolumn{7}{|c|}{ Вироблено (валовий випуск) за } & \multirow[b]{2}{*}{$\begin{array}{c}\text { Відхилення, } \\
+,-\end{array}$} \\
\hline & 2011p. & 2012p. & 2013p. & 2014p. & 2015p. & 2016p. & 2017p. & \\
\hline $\begin{array}{l}\text { Яловичина і телятина, свіжі } \\
\text { чи охолоджені - туші, } \\
\text { напівтуші, четвертини } \\
\text { необвалені, тис.т }\end{array}$ & 62,3 & 60,5 & 62,1 & 54,8 & 50,0 & 59,1 & 56,9 & $-5,4$ \\
\hline $\begin{array}{l}\text { Свинина заморожена - туші, } \\
\text { напівтуші, тис.т }\end{array}$ & 8,3 & 5,9 & 5,3 & 7,0 & 12,4 & 7,4 & 6,6 & $-1,7$ \\
\hline $\begin{array}{l}\text { Кури, курчата (тушки) свіжі } \\
\text { чи охолоджені, тис.т }\end{array}$ & 450 & 422 & 440 & 376 & 326 & 295 & 320 & -130 \\
\hline $\begin{array}{l}\text { Кури, курчата (частини } \\
\text { тушок) свіжі чи охолоджені, } \\
\text { тис.т }\end{array}$ & 228 & 254 & 320 & 313 & 362 & 376 & 454 & 226 \\
\hline $\begin{array}{l}\text { Кури, курчата (тушки) } \\
\text { заморожені, тис.т }\end{array}$ & 31,9 & 36,7 & 89,7 & 48,9 & 145 & 217 & 76,8 & 44,9 \\
\hline $\begin{array}{l}\text { Олія соняшникова } \\
\text { нерафінована та її фракції, } \\
\text { млн.т }\end{array}$ & 3,2 & 3,8 & 3,4 & 4,4 & 3,7 & 4,4 & 5,3 & 2,1 \\
\hline $\begin{array}{l}\text { Продукти харчові з жирів та } \\
\text { олій інші (уключаючи } \\
\text { маргарин рідкий), тис.т }\end{array}$ & 183 & 151 & 139 & 137 & 50,0 & 52,4 & 88,3 & $-94,7$ \\
\hline $\begin{array}{l}\text { Масло вершкове жирністю } \\
\text { не більше } 85 \% \text {, тис.т. }\end{array}$ & 76,2 & 88,1 & 93,9 & 113 & 101 & 102 & 108 & 31,8 \\
\hline
\end{tabular}


Підтвердженням стагнації в переробній галузі АПК є низький рівень рентабельності в галузі, особливо складна ситуація в малих підприємствах. Так у 2017 році рівень збитковості становив $13,9 \%$ та мікропідприємства 7,9\% (табл. 3 ).

За умов погіршення стану продовольчої безпеки, спричиненого різними факторами, погіршилися індикатори - орієнтири розвитку, що визначають межу негативних процесів, подаючи сигнали учасникам ринку про можливі несприятливі сфери, зниження глобального рівня національної безпеки [1].

Оцінка стану продовольчої безпеки передбачає обрахунок 7 індикаторів, які характеризують стан продовольчої безпеки, а саме:

- добова енергетична цінність раціону людини;

- забезпечення раціону людини основними видами продуктів, якими вважаються хліб i хлібопродукти, картопля, овочі, баштанні, фрукти, ягоди і виноград, цукор, олія, м'ясо і м'ясопродукти, молоко і молокопродукти, риба і рибопродукти, яйця;

- достатність запасів зерна у державних ресурсах;

- економічна доступність продуктів;

- диференціація вартості харчування за соціальними групами;

- ємність внутрішнього ринку окремих продуктів;

- продовольча незалежність за окремим продуктом $[2,3]$.

Рентабельність операційної та всієї діяльності підприємств за видами економічної діяльності з розподілом на великі, середні, малі та мікропідприсмства за 2010-2017 роки, \%

\begin{tabular}{|c|c|c|c|c|c|c|}
\hline & Роки & усього & $\begin{array}{c}\text { великі } \\
\text { підприємства }\end{array}$ & $\begin{array}{c}\text { середні } \\
\text { підприємства }\end{array}$ & $\begin{array}{c}\text { малі } \\
\text { підприємства }\end{array}$ & $\begin{array}{c}\text { 3 них } \\
\text { мікропідприємства }\end{array}$ \\
\hline \multirow{8}{*}{ 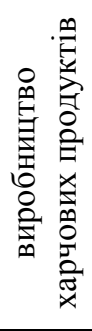 } & 2010 & 0,1 & 0,5 & 0,1 & $-4,2$ & $-12,4$ \\
\hline & 2011 & 0,0 & 2,3 & $-2,3$ & $-3,8$ & $-8,0$ \\
\hline & 2012 & 1,7 & 4,8 & $-1,7$ & $-2,5$ & $-8,8$ \\
\hline & 2013 & 1,4 & 4,1 & $-0,9$ & $-4,8$ & $-19,1$ \\
\hline & 2014 & $-4,5$ & $-2,8$ & $-6,1$ & $-7,9$ & $-24,7$ \\
\hline & 2015 & $-3,2$ & $-3,6$ & $-2,7$ & $-3,5$ & $-12,2$ \\
\hline & 2016 & $-0,9$ & $-0,6$ & $-1,1$ & $-1,4$ & $-6,1$ \\
\hline & 2017 & 1,3 & 3,7 & 1,0 & $-13,9$ & $-7,9$ \\
\hline \multicolumn{2}{|c|}{ Відхилення, (+,-) } & 1,2 & 3,2 & 0,9 & $-9,7$ & 4,5 \\
\hline
\end{tabular}

Джерело: сформовано на основі [1]

Нині рівень продовольчої безпеки є недостатнім, а переробна промисловість АПК не в змозі повною мірою її забезпечити та потребує проведення комплексної реструктуризації більшості підприємств.

На думку Швець О.Ю., проаналізувавши сучасний стан переробної промисловості України можна виокремити головні проблеми, на які натрапляють на своєму шляху українські підприємства у сфері постачання на національний та іноземний ринки конкурентоспроможної продукції:

- скорочення обсягів постачання сировини від сільського господарства, від якого залежать ціна та якість продукції;

- несприятливий клімат для отримання великих обсягів урожаю, через що відбувається помітне скорочення виробництва продукції;

- застаріле обладнання та недосконала техніка обробки сировини;

- відсталість від провідних методик зарубіжних колег полягає в тому, що Україна протягом багатьох років не тільки не відповідає європейським нормам, а й не змінює їх. Якщо розглядати технологію обробки заморожених продуктів харчування в Свропі, то, відповідно до ГСТУ, рівень температури повинен бути $-18^{\circ} \mathrm{C}$, тоді як Україна, відповідно до ГСТУ, встановлює $-12^{\circ} \mathrm{C}$;

- невідповідність міжнародним стандартам якості продукції і, як наслідок, зниження попиту на вітчизняні товари;

- залежність експорту української продукції від попиту на іноземних ринках;

- недостатня забезпеченість фінансовими ресурсами та незначна інвестиційна привабливість для іноземних інвесторів [3. с.73].

Незважаючи на ці фактори, переробна промисловість України за умови правильно обраної стратегії розвитку та відповідної державної підтримки може не лише забезпечити продовольчу безпеки, а й покращити показники експорту. Розроблений проєкт розпорядження Кабінету 
Міністрів України «Про схвалення Стратегії розвитку експорту продукції сільського господарства, харчової та переробної промисловості України до 2026 року», який передбачає визначення довгострокової державної політики, спрямованої на забезпечення стабільного нарощування обсягів експорту продукції (товарів, послуг, технологій) вітчизняного сільського господарства, харчової та переробної промисловості [4].

Стратегічними напрямами розвитку експорту продукції сільського господарства, харчової та переробної промисловості стане зростання обсягу виробництва та збільшення експорту продукції сільського господарства, харчової та переробної галузі, розширення номенклатури та зміна структури експорту в напрямку збільшення частки продукції з високою доданою вартістю (зміну співвідношення між сировиною, продуктами первинної переробки та готовою продукцією у загальному обсязі експортованої продукції сільського господарства, харчової та переробної продукції з 55/34/11 на 39/40/21 на кінець 2026 року), географічна диверсифікація напрямків експорту (відкриття нових ринків) та розширення експортних можливостей для малих та середніх підприємств (табл. 4).

Таблиия 4

Прогноз впливів реалізації Стратегії розвитку експорту продукції сільського господарства, харчової та переробної промисловості України до 2026 року на інтереси учасників аграрного ринку

\begin{tabular}{|c|c|c|c|c|}
\hline \multirow[t]{2}{*}{$\begin{array}{c}\text { Зацікавлена } \\
\text { сторона }\end{array}$} & \multirow[t]{2}{*}{$\begin{array}{l}\text { Ключовий } \\
\text { інтерес }\end{array}$} & \multicolumn{2}{|c|}{$\begin{array}{c}\text { Очікуваний (позитивний чи негативний) } \\
\text { вплив на ключовий інтерес із } \\
\text { зазначенням передбачуваної динаміки } \\
\text { змін основних показників (у числовому } \\
\text { чи якісному вимірі) }\end{array}$} & \multirow{2}{*}{$\begin{array}{l}\text { Пояснення (чому } \\
\text { саме реалізація } \\
\text { акту призведе до } \\
\text { прогнозованих } \\
\text { впливів) }\end{array}$} \\
\hline & & $\begin{array}{c}\text { Короткостроковий } \\
\text { вПлив (до року) }\end{array}$ & $\begin{array}{l}\text { Середньостроковий } \\
\text { вПлив (після року) }\end{array}$ & \\
\hline 1 & 2 & 3 & 4 & 5 \\
\hline $\begin{array}{l}\text { Малі та середні } \\
\text { виробники сільсько- } \\
\text { господарської, } \\
\text { харчо-вої та } \\
\text { переробної } \\
\text { продукції, які мають }\end{array}$ & $\begin{array}{c}\text { Отримання } \\
\text { навичок та } \\
\text { компетенції } \\
\text { для участі у } \\
\text { міжнародній } \\
\text { торгівлі } \\
\end{array}$ & $\begin{array}{c}\text { Позитивний (в } 2019 \\
\text { році створення } \\
\text { інформаційного } \\
\text { інтернет-ресурсу) }\end{array}$ & $\begin{array}{c}\text { Позитивний } \\
\text { (постійне } \\
\text { інформування) }\end{array}$ & $\begin{array}{c}\text { Підвищення } \\
\text { поінформованості } \\
\text { сільськогосподарських } \\
\text { виробників щодо } \\
\text { зовнішніх ринків }\end{array}$ \\
\hline намір експортувати & $\begin{array}{c}\text { Вихід на } \\
\text { зовнішні } \\
\text { ринки }\end{array}$ & Позитивний & $\begin{array}{c}\text { Позитивний (до } 2026 \\
\text { року їх чисельність } \\
\text { складатиме до } 30 \text { \% } \\
\text { від загальної } \\
\text { кількості } \\
\text { експортерів) } \\
\end{array}$ & $\begin{array}{c}\text { Диверсифікація } \\
\text { суб'єктів експорту }\end{array}$ \\
\hline $\begin{array}{l}\text { Виробники } \\
\text { сільськогосподарської, } \\
\text { харчової та перероб- } \\
\text { ної продукції, які } \\
\text { експортують }\end{array}$ & $\begin{array}{c}\text { Розширення } \\
\text { ринків } \\
\text { експорту }\end{array}$ & $\begin{array}{c}\text { Позитивний (до } \\
2020 \text { року відкриті } \\
\text { ринки } 10 \text { ключових } \\
\text { країн) }\end{array}$ & $\begin{array}{c}\text { Позитивний (до } 2026 \\
\text { року відкриті ринки } \\
50 \text { ключових країн } \\
\text { для усіх товарних } \\
\text { груп) } \\
\end{array}$ & $\begin{array}{c}\text { Відкриття ринків } 50 \\
\text { країн }\end{array}$ \\
\hline & $\begin{array}{c}\text { Захист } \\
\text { інтересів на } \\
\text { зовнішньому } \\
\text { ринку }\end{array}$ & $\begin{array}{c}\text { Позитивний (з } 2018 \\
\text { року план-графік } \\
\text { торгових місій та } \\
\text { переговорних } \\
\text { процесів } 3 \\
\text { визначеними } \\
\text { країнами) }\end{array}$ & $\begin{array}{c}\text { Позитивний (2019- } \\
2020 \text { рр. зміну } \\
\text { співвідношення між } \\
\text { сировиною, } \\
\text { продуктами } \\
\text { первинної переробки } \\
\text { та готовою } \\
\text { продукцією у } \\
\text { загальному обсязі } \\
\text { експортованої } \\
\text { продукції сільського } \\
\text { господарства, } \\
\text { харчової та } \\
\text { переробної } \\
\text { продукції з 55/34/11 } \\
\text { на 39/40/21 на кінець } \\
\text { 2026 року) }\end{array}$ & $\begin{array}{c}\text { Ініціювання } \\
\text { торгових місій, } \\
\text { переговорів щодо } \\
\text { поліпшення умов } \\
\text { доступу на ринки }\end{array}$ \\
\hline
\end{tabular}




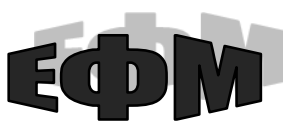

http://efm.vsau.org/

Продовження табл. 4

\begin{tabular}{|c|c|c|c|c|}
\hline 1 & 2 & 3 & 4 & 5 \\
\hline $\begin{array}{l}\text { Експортери } \\
\text { неякісної продукції } \\
\text { сільського } \\
\text { господарства, та } \\
\text { харчової } \\
\text { переробної } \\
\text { промисловості }\end{array}$ & $\begin{array}{c}\text { Можливість } \\
\text { експорту } \\
\text { неякісної } \\
\text { продукції }\end{array}$ & Негативний & Негативний & $\begin{array}{c}\text { Розроблення та } \\
\text { запровадження } \\
\text { механізмів } \\
\text { відповідальності за } \\
\text { поставку неякісної } \\
\text { продукції сільського } \\
\text { господарства, } \\
\text { харчової та } \\
\text { переробної } \\
\text { промисловості }\end{array}$ \\
\hline
\end{tabular}

Джерело: сформовано на основі [4]

У сфері експорту продукції сільського господарства, харчової та переробної промисловості залишається значна питома вага сировинної продукції, відносно незначна номенклатура, недостатнє залучення малих та середніх підприємств до експорту, ускладнений доступ до ринків. Експортна стратегія визначає поступовий перехід до експорту продукції з високою доданою вартістю та реалізації потенційних ринкових можливостей на зовнішніх ринках [4].

Проте в зазначеному проєкті стратегії відсутні чіткі пропозиції та кроки щодо проведення комплексної реструктуризації цих підприємств та виокремлення найбільш перспективних напрямків розвитку.

Реструктуризація як виробничий процес і управлінська діяльність в аграрних підприємствах має за мету здійснення змін елементів системи господарювання за такими основними напрямами: правовий (зміна форм власності); управлінський (організаційно-функціональне упорядкування); фінансовий (відтворення вартості та забезпечення інноваційного розвитку); виробничий (впровадження досягнень науково-технічного прогресу i новітніх виробничих технологій); збутовий (маркетинг) [5, с. 5].

Особливу увагу варто звернути на розвиток малої переробної кооперації на селі, що дасть можливість створити малим виробникам сільськогосподарської продукції переробні виробництва 3 метою реалізації власної продукції на місцевих ринках.

Комплекс заходів з адаптації підприємств переробних галузей АПК до сучасних реалій повинен бути спрямований на:

- оновлення основних засобів підприємств;

- врегулювання нормативного забезпечення заходів із фінансової реструктуризації підприємств та державної підтримки;

- розробка алгоритмів комплексної реструктуризації підприємств;

- адаптація стандартів продукції до вимог ЄС;

- проведення державної підтримки створення малих переробних підприємств обслуговуючого типу (рис. 1).

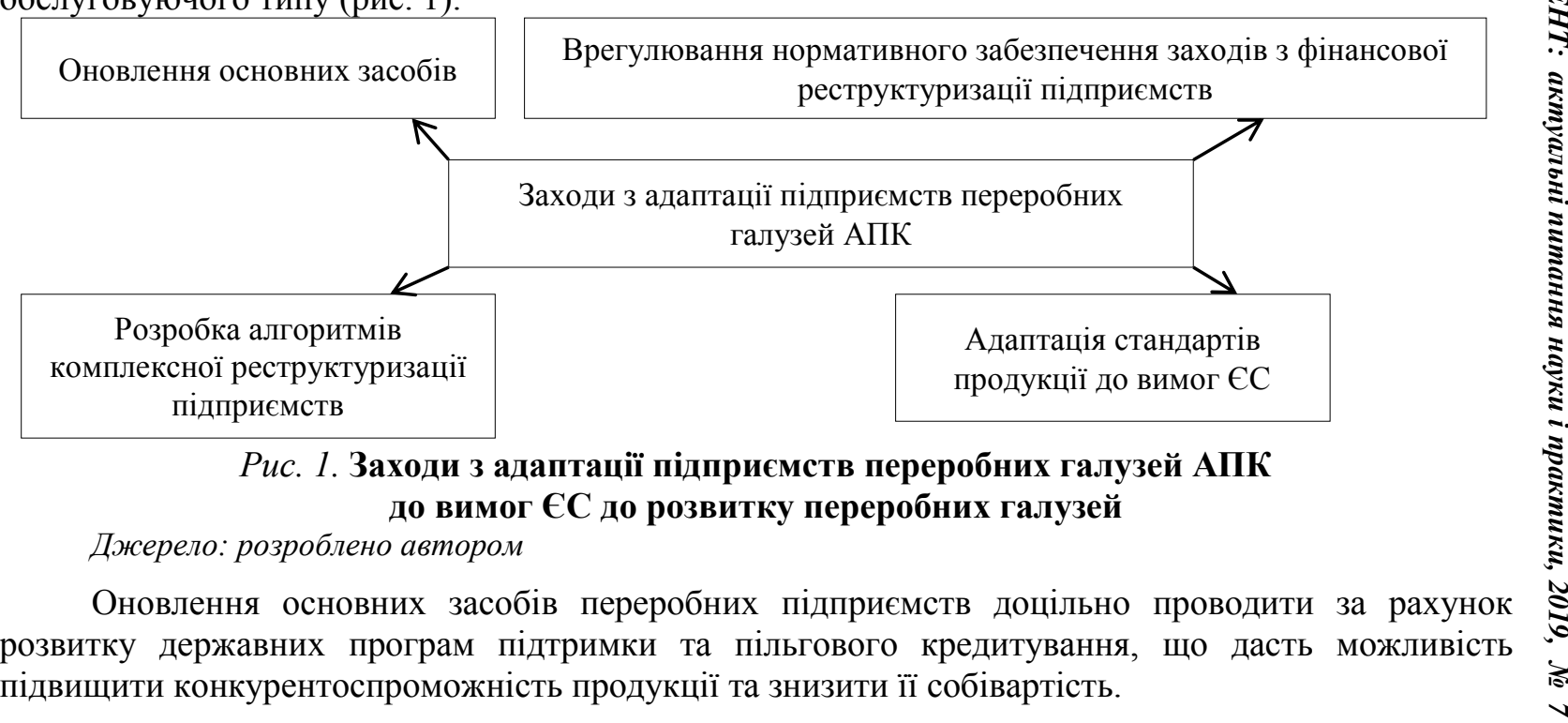


Одним із основних законодавчих актів, що регулюють фінансову реструктуризацію, є Закон «Про фінансову реструктуризацію» від 14 червня 2016 року № 1414-VIII, що набрав чинності 19 жовтня 2016 року терміном на 3 роки. В ньому передбачено врегулювання заборгованості без звернення до суду, 3 використанням досить нових дієвих механізмів здійснення ефективної фінансової реструктуризації за допомогою порівняно нових незалежних органів: Спостережної ради, Секретаріату та Арбітражного комітету та з обов'язковим отриманням звіту незалежного експерта про проведення огляду фінансово-господарської діяльності боржника, який включає в себе висновок про перспективність такої діяльності. У цьому нормативному акті чітко визначено правила розв'язання суперечок між кредитором та позичальником. Вводиться мораторій на позови проти боржника. У разі узгодження реструктуризації позичальник звільняється від сплати податку на прибуток і ПДВ. Визначено терміни, коли реструктуризація має бути завершена - це 180 днів. Суперечки розв'язує незалежний арбітражний комітет. Також $є$ законна можливість часткового списання суми кредиту [5].

Подальший розвиток нормативного забезпечення має бути спрямований на адаптацію законодавства у сфері регулювання стандартів якості продукції переробної промисловості та підтримки розвитку малих переробних підприємств у формі обслуговуючих кооперативів.

Нині розвиток обслуговуючої кооперації в сільських територіях, на нашу думку, варто проводити на прикладі «Програми розвитку особистих селянських, фермерських господарств, кооперативного руху на селі та дорадництва на 2016-2020» Вінницького регіону, спрямованої на підтримку та розвиток особистих селянських господарств у регіоні, фермерських господарств та сільськогосподарських обслуговуючих кооперативів як рівноправних форм господарювання в сільській місцевості в умовах сьогодення, закріплення позитивних тенденцій у їхній діяльності. Програмою передбачається також подальший розвиток в галузі інфраструктури аграрного ринку регіону, дорадництва та сільського зеленого туризму [7].

Подальший розвиток відповідних програм повинен бути спрямований на створення не лише сільськогосподарських обслуговуючих кооперативів, а й переробних кооперативів, діяльність яких буде спрямована на переробку сільськогосподарської продукції з подальшою ії реалізацією (овочепереробні, виробництво соків, виробництво екологічно чистої продукції). Також доцільно було б розвивати переробні кооперативи, спрямовані на виробництво біодизеля, діяльність яких орієнтувалася б на переробку насіння олійних культур на біодизель та для потреб галузі тваринництва (жмих). Створення та державна підтримка такого виду кооперативів дасть можливість досягти таких позитивних результатів:

1) створення додаткових робочих місць у сільській місцевості;

2) розвиток високотехнологічного виробництва ліній з переробки олійних культур;

3) забезпечення малих сільгоспвиробників біодизелем для власних потреб та високонцентрованими кормами галузі тваринництва.

Розробка алгоритмів комплексної реструктуризації має передбачати створення універсальних механізмів, які будуть комплексно поєднувати заходи з виробничої, управлінської та фінансової реструктуризації підприємств і забезпечувати високу ефективність цих заходів.

На думку Конишева В.А., методологія реструктуризації підприємства має вирішувати такі завдання:

- забезпечити стратегічне планування видів діяльності, котре має визначити перспективні напрями реструктуризації підприємств;

- здійснити процесний підхід до управління підприємством, що дасть змогу сконцентрувати ресурси на реструктуризації та більш ефективно їх використовувати в подальшому;

- реалізувати управління знаннями на всіх етапах реструктуризації, забезпечуючи вибір адекватних проєктних рішень, грунтуючись на особливостях потенціалу підприємства [8].

Тому створення універсальних алгоритмів проведення реструктуризації є необхідним для підприємств різних переробних галузей АПК. Так, для прикладу, механізм реструктуризації спиртових заводів має включати комплекс заходів, які передбачатимуть модернізацію виробництва зі створенням допоміжних виробництв, зорієнтованих на виробництво біогазу, розробкою відповідної проєктної документації, залученням інвестиційних ресурсів та оптимізацією управлінської системи підприємством.

Щодо сертифікації та стандартизації, при виробництві продукції АПК є досить значні невідповідності між вітчизняною і світовою практикою.

В Україні стандартизація та сертифікація є обов'язковою практично для усієї продукції, водночас через застарілі нормативи вони не забезпечують якість і не гарантують безпеки. Обов'язкові стандарти змушують виготовляти та реалізовувати продукцію, яка відповідає 


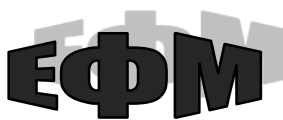

http://efm.vsau.org/

встановленим державою нормам. У країнах $С С$ використовують дві категорії технічних вимог до видів продукції, а не до окремих товарів. Перша категорія - це рекомендовані до використання вимоги, що підтверджують відповідність обов'язковим директивам АСА. Таких вимог $10 \%$ і вони забезпечують безпеку та здоров'я споживача. Решта стандартів, які стосуються таких параметрів, як послуги, якість, надійність, міцність є суто добровільними. В ЄС питаннями сертифікації займаються три організації: Європейський комітет з питань стандартизації (CEN), Європейський комітет з питань електротехнічної стандартизації (Cenelec), а також Європейський інститут зі стандартизації в галузі телекомунікації (ETSI). Використання єдиних стандартів CEN та Cenelec на всій території європейського ринку гарантує захист прав споживача, сприяє торгівлі, забезпечує сумісність продуктів, сприяє розвитку та впровадженню інноваційних технологій, забезпечує екологічний захист навколишнього середовища [8, с. 1035].

Окрім невідповідності в методах стандартизації та сертифікації для переробних галузей АПК на теперішній час існує досить велика проблема якісної сировини. Особливо це стосується молокопереробних підприємств. Більшість молока в Україні виробляється особистими селянськими господарствами і не відповідає міжнародним стандартам. Окремі молокопереробні підприємства, наприклад ТОВ «Літинський молочний завод», створюють власні фермерські господарства європейського типу.

На сьогодні у ПОСП «Нападівське», яке створене ТОВ «Літинський молочний завод», нараховується 2200 голів великої рогатої худоби, з них 900 голів дійного стада із продуктивністю 9600 кг на корову на рік. Для порівняння - у 2013 році було лише 146 голів великої рогатої худоби. Розведення дійного поголів'я корів голштинської породи почалося із 300 українських та 100 чеських нетелей. Годівля корів проводиться спеціально підібраним, збалансованим раціоном. А тварини утримуються у чистоті та ідеальних для їхнього здоров'я умовах: без прив'язі, під навісом на свіжому повітрі, з вільним доступом до кормового столу та води, у максимально наближених до природніх умовах. Зоотехніки користуються голландською програмою управління стадом. Продуктивність молочного комплексу становить 23 тони екологічно чистого молока за добу. Доїння корів проводиться у доїльній залі з ізраїльським обладнанням, обробляють спеціальними дезінфікуючими засобами. Така система дозволяє виключити контакт молока з людиною та іншими сторонніми факторами що дає можливість отримати високоякісний продукт.

Створення аналогічних підприємств за рахунок прибутків потужних молокопереробних заводів дасть спільно $з$ державною підтримкою молочного скотарства можливість вирішити низку завдань:

- забезпечення молокопереробних підприємств високоякісною сировиною;

-зменшення собівартості виробництва;

- створення додаткових робочих місць на селі;

- розвиток галузі тваринництва;

-зростання ВВП.

Стосовно оновлення основних засобів підприємств переробної сфери АПК варто зазначити, що воно має бути спрямоване на комплексне оновлення всієї виробничої структури підприємств $\mathrm{i}$ відповідати розробленому алгоритму реструктуризації окремо взятого підприємства.

Оновлення основних засобів на підприємствах переробної сфери АПК можливо за рахунок створення програм державного пільгового кредитування, а також залучення субвенцій 3 державного бюджету, особливо це стосується підприємств ДП «Укрспирт».

До основних чинників, що підвищують ефективність використання виробничого потенціалу підприємств харчової індустрії, на думку Меліх Т.В., через інтеграційні процеси варто віднести:

1) оптимізацію бізнес-процесів;

2) інвестиції у виробництво конкурентоспроможної рентабельної продукції, збереження та покращення якості продукції;

3) зниження витрат на виробництво та збут продукції, оптимальне ціноутворення;

4) розширення асортименту, своєчасне виведення на ринок нової продукції, нові цінові пропозиції для різних категорій споживачів, збалансований портфель брендів;

5) удосконалення системи дистрибуції, розвиток власної торговельної мережі;

6) інвестиції в збільшення та модернізацію виробничих потужностей, енергетичні проєкти;

7) впровадження інноваційних технологій;

8) орієнтація на диверсифікацію ринків, врахування потреб внутрішнього та зовнішнього ринків, розширення експорту;

9) створення та розвиток власної сировинної бази тощо [10, с. 456]. 
Отже, за умов низької конкурентоспроможності переробної галузі АПК на світових ринках потрібно також здійснювати заходи з інтеграції цих підприємств у світовий економічний простір, які включатимуть:

1) імпорт виробничих технологій;

2) перехід на світові стандарти якості продукції;

3) створення спільних підприємств з іноземними інвесторами;

4) реалізація Стратегії розвитку експорту продукції сільського господарства, харчової та переробної промисловості України до 2026 року;

5) створення представництв великих переробних підприємств за кордоном тощо.

Висновки. Розвиток переробних галузей АПК в умовах інтеграції національної економіки у світовий економічний простір є одним із першочергових завдань для держави.

Найбільш перспективними напрямками розвитку цього сектору економіки є:

- комплексна реструктуризація підприємств ДП «Укрспирт» 3 орієнтацією на виробництво біоетанолу;

- створення за рахунок прибутків великих молокопереробних підприємств власних молочнотваринницьких ферм для забезпечення високоякісною сировиною;

- залучення іноземного інвестора та технологій для створення спільних підприємств;

- створення державних програм підтримки розвитку переробної кооперації в сільській місцевості та молочного скотарства;

- адаптація виробничих потужностей до світових стандартів якості.

Реалізація зазначених напрямків розвитку дасть можливість:

- здійснити запуск спиртових заводів ДП «Укрспирт», які на теперішній час є банкрутами, збільшити прибутковість концерну, створити додаткові робочі місця та наростити ВВП, а також зменшити рівень енергетичної залежності держави;

- забезпечити великих товаровиробників молоком, яке б відповідало стандартам СС;

- наростити обсяг валютних інвестицій в агропромисловий сектор;

- створити додаткові робочі місця на селі за рахунок створення кооперативів та зменшити www.ukrstat.gov.ua

2. Калетнік Г.М. Дармограй О.В. Методичні підходи до оцінки та аналіз індикаторів продовольчої безпеки України. Економіка. Фінанси. Менеджмент: актуальні питання науки $i$ практики. 2016. № 6. С. 7-20.

3. Швець Ю.О., Бутенко А.А. Аналіз сучасного стану харчової промисловості України на внутрішньому та зовнішньому ринках. Науковий вісник Міжнародного гуманітарного університету. Серія: Економіка і менеджмент. 2018. Вип. 30. С. 71-74.

4. Про схвалення Стратегії розвитку експорту продукції сільського господарства, харчової та переробної промисловості України до 2026 року: проект / М-во аграр. політики та продовольства України. URL: http://minagro.gov.ua/uk/organic_ministry?nid=26738 (дата звернення: 8.07.2019)

5. Мазур А.Г. Економічна сутність та зміст реструктуризації аграрних підприємств в умовах транзитивної економіки. Економіка, фінанси, менеджмент: актуальні питання науки і практики. 2015. № 2. C. 3-12.

6. Про фінансову реструктуризацію : Закон України від 14 червня 2016 року № 1414-VIII. URL: https://zakon.rada.gov.ua/laws/show/1414-19 (дата звернення: 8.07.2019).

7. Про програму розвитку особистих селянських, фермерських господарств, кооперативного руху на селі та дорадництва на 2016-2020 роки / Вінницька ОДА URL: http://www.vin.gov.ua/depapr/normatyvno-pravova-baza/278-prohramy-pidtrymky-apk/1855-prohrama-rozvytku-osobystykh-selianskykhfermerskykh-hospodarstv-kooperatyvnoho-rukhu-na-seli-ta-doradnytstva (дата звернення: 8.07.2019).

8. Конышев В.А. Применение инновационных технологий в рестуктуризации предприятияй. Вестник ОГУ. 2012. № 1(137). С. 107.

9. Саєнко Я. А., Недбалюк О. П. Адаптація вітчизняних підприємств до стандартів якості продукції на ринку Європейського Союзу. Молодий вчений. 2017. № 10. С. 1033-1036.

10. Меліх Т.Г. Інтеграція підприємств харчової промисловості як фактор оптимізації використання виробничого потенціалу. Інфрастуруктура ринку. Випуск № 14. Грудень 2016 р. С. 450-457 


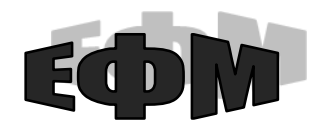

http://efm.vsau.org/

11.Калетнік Г.М., Козловський С.В., Кірєєва Е.А., Підвальна О.Г. Управління регіональною продовольчою безпекою в умовах економічної нестабільності: монографія. Вінниця: МеркъюріПоділля, 2015. $251 \mathrm{c.}$

\section{References}

1. Sait Derzhavnoi sluzhby statystyky Ukrainy. [Elektronnyi resurs]. Rezhym dostupu: www.ukrstat.gov.ua

2. Kaletnik, H.M. \& Darmohrai, O.V. (2016). Metodychni pidkhody do otsinky ta analiz indykatoriv prodovolchoi bezpeky Ukrainy. [Methodological approaches to the assessment and analysis of food safety indicators of Ukraine]. Ekonomika. Finansy. Menedzhment: aktualni pytannia nauky i praktyky. 2016. № 6. S. 7-20. [in Ukrainian].

3. Shvets, Y.O., Butenko, A.A. (2018). Analiz suchasnoho stanu kharchovoi promyslovosti Ukrainy na vnutrishnomu ta zovnishnomu rynkakh. [Analysis of the current state of the food industry of Ukraine in the domestic and foreign markets]. Naukovyi visnyk Mizhnarodnoho humanitarnoho universytetu. Seriia: Ekonomika i menedzhment. 2018. Vyp. 30. S. 71-74. [in Ukrainian].

4. Pro skhvalennia Stratehii rozvytku eksportu produktsii silskoho hospodarstva, kharchovoi ta pererobnoi promyslovosti Ukrainy do 2026 roku. : proekt [On Approval of the Strategy for Exporting Agricultural Products, Food and Processing Industry of Ukraine to 2026] / M-vo ahrar. polityky ta prodovolstva Ukrainy. URL: http://minagro.gov.ua/uk/organic_ministry?nid=26738 (data zvernennia: 8.07.2019) [in Ukrainian].

5. Mazur, A.H. (2015). Ekonomichna sutnist ta zmist restrukturyzatsii ahrarnykh pidpryiemstv $v$ umovakh tranzytyvnoi ekonomiky. [Economic essence and content of restructuring of agrarian enterprises in the conditions of a transitory economy]. Ekonomika, finansy, menedzhment: aktualni pytannia nauky i praktyky. № 2. S. 3-12. [in Ukrainian].

6. Pro finansovu restrukturyzatsiiu [About financial restructuring] : Zakon Ukrainy vid 14 chervnia 2016 roku № 1414-VIII. URL: https://zakon.rada.gov.ua/laws/show/1414-19 (data zvernennia: 8.07.2019). [in Ukrainian].

7. Pro prohramu rozvytku osobystykh selianskykh, fermerskykh hospodarstv, kooperatyvnoho rukhu na seli ta doradnytstva na 2016-2020 roky [About the program of development of personal peasant, farm, cooperative movement in the village and counseling for 2016-2020] / Vinnytska ODA URL: http://www.vin.gov.ua/dep-apr/normatyvno-pravova-baza/278-prohramy-pidtrymky-apk/1855-prohramarozvytku-osobystykh-selianskykh-fermerskykh-hospodarstv-kooperatyvnoho-rukhu-na-seli-tadoradnytstva (data zvernennia: 8.07.2019). [in Ukrainian].

8. Konyshev, V.A. (2012). Prymenenye ynnovatsyonnykh tekhnolohyi $v$ restukturyzatsyy predpryiatyiai. [The use of innovative technologies in the restructuring of enterprises]. Vestnyk OHU. № 1(137). S. 107. [in Ukrainian].

9. Saienko, Y.A., Nedbaliuk O.P. (2017). Adaptatsiia vitchyznianykh pidpryiemstv do standartiv yakosti produktsii na rynku Yevropeiskoho Soiuzu. [Adaptation of competitive companies to the standards of products to the market of the European Union]. Molodyi vchenyi. 2017. № 10. S. 1033-1036. [in Ukrainian].

10.Melikh T.H. (2016). Intehratsiia pidpryiemstv kharchovoi promyslovosti yak faktor optymizatsii vykorystannia vyrobnychoho potentsialu.[ Integration of food industry enterprises as a factor in optimizing the use of production potential]. Infrasturuktura rynku. Vypusk № 14. Hruden. S. 450-457. [in Ukrainian].

11. Kaletnik, H.M., Kozlovskyi, S.V., Kirieieva, E.A., Pidvalna, O.H. (2015). Upravlinnia rehionalnoiu prodovolchoiu bezpekoiu $v$ umovakh ekonomichnoi nestabilnosti [Managing Regional Food Security in Conditions of Economic Instability]: monohrafiia. Vinnytsia: Merkbiuri-Podillia. 251 s. [in Ukrainian].

\section{Відомості про автора}

ГОНТАРУК Ярослав Вікторович - асистент кафедри аграрного менеджменту, Вінницький національний аграрний університет $(21008$, м. Вінниця, вул. Сонячна, 3, e-mail: e050122015@gmail.com).

GONTARUK Yaroslav - assistant of the department of agrarian management, Vinnytsia National Agrarian University (21008, Vinnytsia, 3, Solnyschaya St., e-mail: e050122015@gmail.com).

ГОНТАРУК Ярослав Викторович - ассистент кафедры аграрного менеджмента, Винницкий национальный аграрный университет (21008, г. Винница, ул. Солнечная, 3, e-mail: e050122015@gmail.com). 